IRSH 60 (2015), Special Issue, pp. 253-273 doi:I0.1017/So0208590 I 5000395

(C) 2015 Internationaal Instituut voor Sociale Geschiedenis

\title{
Football, Migration, and Coalmining in Northern France, I920s-1980s
}

\author{
MARION FONTAINE \\ Centre Norbert Elias, Université d'Avignon et des Pays de Vaucluse \\ 74 rue Louis Pasteur, 84029 Avignon, France \\ E-mail: marion.fontaine@univ-avignon.fr
}

\begin{abstract}
AвSTRACT: Football is often thought to have helped erase differences between natives and migrants in mining communities and to have helped in building a homogeneous class identity. Others have described this idea as a myth. Under closer scrutiny, however, relations between migrants and football are more complex than commonly thought. This article will elaborate on these complex relations by analysing the case of the coalfield in the French region of Nord-Pas-de-Calais during the twentieth century. Migrant workers were employed there from an early date: first, from the I920s, Poles; later on other migrants, especially of Moroccan and Algerian descent. Migrants played an important role in the development of football in this region. This article looks at the influence of football on relations between migrants and other miners. More generally, it aims to show how sport was incorporated into the industrial mining world, both in employers' policies and in the mining community.
\end{abstract}

In April 1955 the company newspaper Douai Mines, published by the state-owned Houillères nationales du Bassin Nord-Pas-de-Calais and named after Douai, one of the coalfield's larger cities, printed a map localizing the mining roots of some young football celebrities, from Maryan Wisniewski to Raymond Kopaszewski (the famous Kopa) ${ }^{\mathrm{I}}$ and Robert Budzinski, in the localities of Calonne-Ricouart to Auchel and Noeux-les-Mines in the coalfield in the north of France. Along with the map came an article (see Figure I), with the following statement: "Coalmining, a harsh school of life, has rough names, who together form the wealth of French football." ${ }^{2}$ The sentence and the reference to "rough" names emphasize the connections between football, coalmining, and migrant - in this case Polish - communities.

I. Raymond Kopaszewski was born in I93 I in Noeux-les-Mines into a family of Polish miners. In the r 950 s he became a legendary footballer with a national and international career. Today, he is seen as the first great "star" of contemporary French football.

2. "Une mine [...] de footballeurs", Donai Mines, April i955. The author writes of a "rude école de la vie", and of "noms rudes". All translations are mine. 


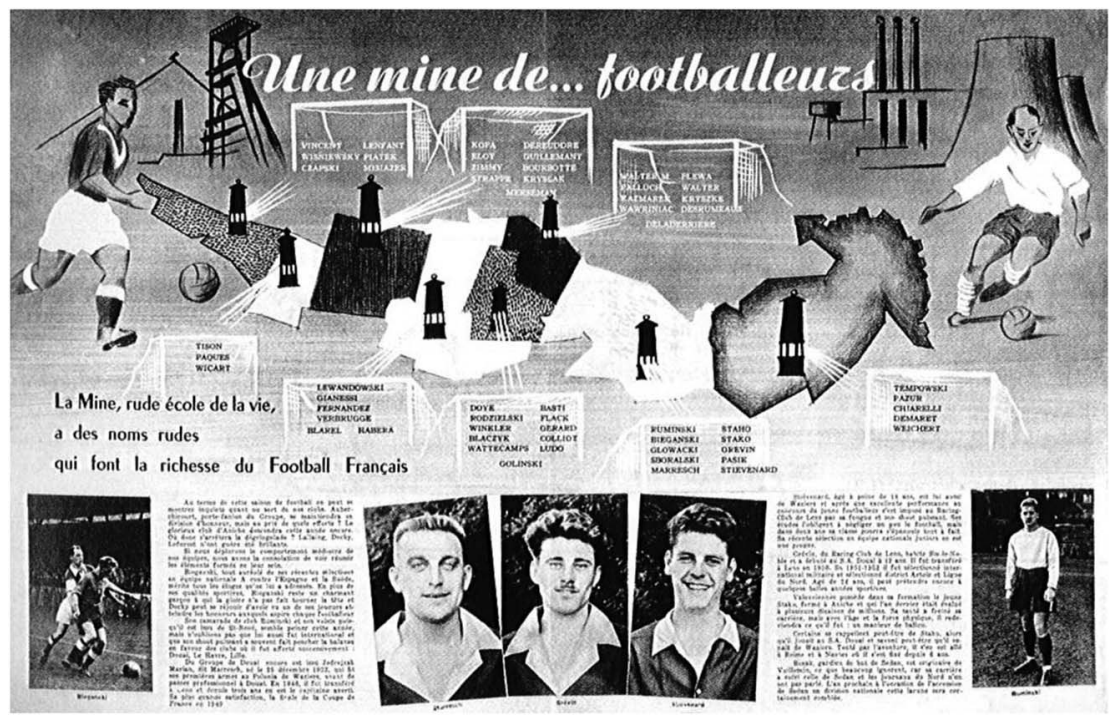

Figure r. "Une mine de... footballeurs". Douai Mines, April 1955 .

This connection was an effect not only of the company's advertising strategy, which sought to highlight the overall importance of the coalfield for France. From the i95os onwards especially, children of Polish migrants were indeed very present in professional and non-professional football clubs. Some of them, like Kopa, Wisniewski, and Budzinski even played in the French national team. Today, this type of player is collectively remembered as a symbol (or myth) of the integrative power of football, both as a medium and as a reflection of the integration of immigrants into the French Republic. ${ }^{3}$ This idea is also present in local collective memory. In the northern coalmining area, football is thought to have helped erase the differences between natives and migrants and to have helped in building a homogeneous class identity. This point is most often highlighted in the case of Polish migrants, who comprised a large part of the mining workforce in northern France. Indeed, a recent historical overview claimed that "Football in coalmining was an ideal place to closely integrate boys who had different origins and backgrounds. It was a way to provide social promotion."

3. This is especially true for Raymond Kopa. For an analysis of how this myth functioned in the case of Kopa and others, see, for instance, Xavier Béal, "Football et immigration: les figures de Kopa, Platini, Zidane dans les médias”, http://www.wearefootball.org/PDF/venus-d-ailleurs.pdf; accessed I 3 December 2009.

4. Centre Historique Minier de Lewarde, Coup Franc, Journal édité pour la Coupe du Monde de Football par le Centre Historique Minier de Lewarde et Mémoires et Cultures de la Région Minière (Lewarde, 1998), p. I. 
While this kind of representation, in which myth and reality are closely intertwined, may exist in other countries as well (as in Germany), it nevertheless takes on special significance and meaning in France. Generally speaking, this vision of the integrative power of sport is very powerful in contemporary French society. It merges with a major dimension of the republican project, namely the construction of an individual and political citizenship that would erase ethnic, cultural, and religious differences. ${ }^{5}$ France's republican tradition renders any official recognition of race or ethnic origin illegitimate. Cultural identity or "community" - the word is often derogatory in France - are seen at best as an anachronism, and at worst as a threat to the unity and the values of the French Republic. Thus, if sport can have a political function, it is only as a means to homogenize ethnic and cultural heterogeneity, and not as a way to express a particular identity in the public sphere.

Over the past few decades, however, French historians and sociologists building on the work of other researchers from Europe and the United States - have produced critical analyses of these processes and representations. The work of Gérard Noiriel can be considered seminal in this regard. ${ }^{6} \mathrm{He}$ was one of the first historians to take seriously the importance of immigration in the history of the French working class. He showed that there may have been some negative consequences of the republican vision of nation and of citizenship contributing not to the integration of immigrants in French society but to their exclusion. Following Noiriel's lead, numerous studies have been published to develop these themes further, especially with regard to the successive waves of migration in France during the twentieth century. ${ }^{7}$ More recently, a number of studies have been undertaken in a similar vein, this time extending into the world of sport. ${ }^{8}$ They have been concerned, in particular, with the reasons why the idea of integration through sport has become such a veritable myth, linked to the French conception of the nation. At the same time, these studies have attempted to clarify, in a concrete and analytical manner, the ambivalent role that modern sport - both as practice and as spectacle - may have played in the relationships between migrant and native.

5. For recent assessments of French republicanism see, for instance, Pierre Rosanvallon, Le modèle politique français. La société française contre le jacobinisme (Paris, 2004); Edward Berenson, Vincent Duclert, and Christophe Prochasson (eds), The French Republic: History, Values, Debates (New York, 201 I).

6. Gérard Noiriel, Le creuset français: histoire de l'immigration XIXe-XXe siècle (Paris, 1988).

7. For a summary of this research by the initiator himself, see idem, Immigration, antisémitisme et racisme en France (XIXe-XXe siècle): discours publics, bumiliations privées (Paris, 2007).

8. See, for instance, Stéphane Beaud and Gérard Noiriel, "L'immigration dans le football", Vingtième Siècle. Revue d'histoire, 26 (1990), pp. 83-96; William Gasparini (ed.), "L'intégration par le sport", Sociétés contemporaines, 69 (2008); Laurent Dubois, Soccer Empire: The World Cup and the Future of France (Los Angeles, CA, 201 I). 
It is this context that defines the scope of the present article. Beyond an abstract tribute to the integrative power of sport, it aims to explore and explain how football could alternately strengthen and erase the boundaries inside the mining communities in Nord-Pas-de-Calais, the most important of their kind in France. Based on extensive research on the coalfield's major football club, Racing Club de Lens, ${ }^{9}$ this article tackles this issue in two major directions.

First, I will consider not only Polish migrants from the I920s to the I940s, but also other migrants - especially those of Moroccan and Algerian descent - who arrived after World War II. The comparison between different migratory waves allows one to understand better the ambivalent effects of sporting activities on the mining community at different periods. It will also help to transcend the stereotypes that, as in the United States (in a slightly different form), frequently place the "old" migrants in opposition to the "new": in this case, those with European origins versus those from the former French colonies in Africa.

Secondly, the article will stress the impact of the changing situation of the French mining industry. While the industry was nationalized at the end of World War II, from the I960s on economic difficulties led to the closure of more and more pits and the mining communities began to disintegrate. This framework is essential in understanding the sporting relations between indigenous inhabitants and immigrants of different origin arriving at different moments. More generally, this article seeks to understand how sport was incorporated into the industrial mining world, both in terms of employers' policies (including their management of the labour market and social policies) and of social change in the mining communities.

\section{THE MINING COMMUNITIES OF NORTHERN FRANCE}

Since the nineteenth century, the development of a coalmining industry in the area ranging from the towns of Béthune to Valenciennes in northern France has been a source of profound, sometimes disruptive economic, political, social, and cultural change. ${ }^{10} \mathrm{New}$ industrial towns emerged, whose activities were all coal-related. The population of these towns grew very fast: the number of inhabitants in a city like Lens, one the most

\footnotetext{
9. See also Marion Fontaine, Le Racing Club de Lens et les "Gueules Noires": Essai d'histoire sociale (Paris, 2010).

Io. For a general history of the coalfield see Marcel Gillet, Les charbonnages $d u$ Nord de la France au XIXe siècle (Paris [etc.], I973). A comparative study of the emerging labour movements in the coalmining industries of western Europe can be found in Joël Michel, "Le mouvement ouvrier chez les mineurs d'Europe occidentale (Grande-Bretagne, Belgique, Allemagne, France): étude comparative des années I880-19I4" (Ph.D. dissertation, Université de Lyon II, I987).
} 


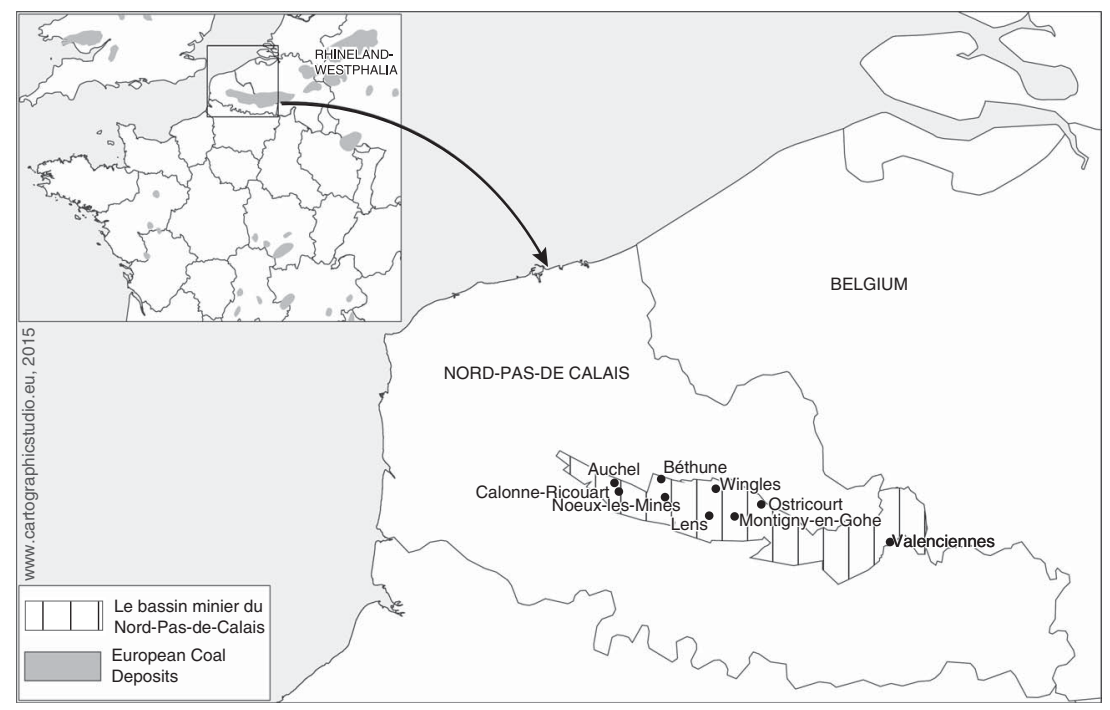

Figure 2. The northern mining region in September 1948 after the nationalization of the coal companies (which became groupes within the Houillères nationales du Bassin Nord-Pas-deCalais [HBNPC]).

Centre Historique Minier de Lewarde. Used with permission.

important in the northern region, rose from 2,700 in I 85 I to 3 I, 800 in I 93 I. In the same period, formerly rural landscapes were transformed by the new pits and by infrastructural developments related to the coal industry. The owners of the private coal companies not only wanted to control the workforce during working hours, they also interfered in the everyday life of their workers: employers built new villages and new living quarters for their workers, and organized facilities for health, education, and leisure. ${ }^{\text {II }}$

This kind of employer paternalism had a pragmatic aim: it was meant to attract workers and to reduce the mobility of the mineworkers, who were frequently looking for better paid and more secure jobs. While World War I brought about the destruction of a significant number of industrial coalmining facilities in northern France, this did not result in a weakening of this paternalistic management. On the contrary, in the I920s new industrial villages were built close to the coalmining pits and their related infrastructure. While working methods and operating procedures were partly modernized, employer control over the mining communities remained.

The mining world was neither unified and homogenous, however, nor completely under the control of the employers. On the contrary, the 
northern coalmining region was socially diverse and divided, and miners' unions were very strong, much like their British and German counterparts. ${ }^{\mathrm{I} 2}$ Political divisions were very important, especially after the French labour movement was divided into socialists and communists in 1920. Moreover, those inhabiting the mining quarters and working for the same company had different status positions, along with different duties and privileges. The size of the houses of workers, foremen, and engineers differed relative to the inhabitants' positions in the company hierarchy. This structure fuelled the rivalries, resentment, gossip, and opposition that were an integral part of life in mining communities, as well as moments of unity and collective experience, whether tragic (as after a mining disaster) or festive. ${ }^{13}$

A similar heterogeneity could be found in the domain of leisure. There were many leisure associations, often located in cafés, ${ }^{\mathrm{I}}{ }^{4}$ ranging from amateur theatre groups and jeu-de-boules clubs to choral societies, to name just a few. Even in the field of leisure, interference by the employers was very strong. During the interwar period mining companies, in an attempt to monitor miners also in their leisure time, operated sports fields and other sport facilities, and many sports clubs were organized by the employers, often with a pit engineer or a teacher from the mining school serving as president. ${ }^{\text {Is }}$ These sports clubs were named after the miners' neighbourhoods, such as Saint-Pierre, Saint-Théodore, and Saint-Edouard. Their original activities had been gymnastics and military training, but in the I920s, following a general trend in society, the nature of their physical activities changed and the older ones, like gymnastics, were replaced by new kinds of sport that were both competitive and team-based as well as rooted in mass culture - particularly football ${ }^{16}$ and basketball.

I2. For studies emphasizing this diversity see Philippe Ariès, "Au Pays noir, la population minière du Nord-Pas-de-Calais", in idem, Histoire des populations françaises (Paris, I97I), pp. 69-1 I8; Claude Dubar, Gérard Gayot, and Jacques Hédoux, "Sociabilité minière et changement social à Sallaumines et à Noyelles-sous-Lens”, Revue du Nord, 253 (1982), pp. 365-463.

I3. For a study of a similar intermingling of social and local neighbourhood identities in the case of the Italian city of Turin, see Daniel Jalla and Florence Baptiste, "Le quartier comme territoire et comme représentation: les 'barrières' ouvrières de Turin au début du XXe siècle”, Le Monvement Social, i I 8 (1982), pp. 79-97.

I4. Milan Vulic, "Le cabaret, le bistrot, lieu de la sociabilité populaire dans le bassin houiller du Nord-Pas-de-Calais (1750-1985)” (Ph.D. dissertation, Université de Lille III, I990), pp. 205-3I 2.

I 5. Archives Départementales du Pas-de-Calais, Dainville, France (hereafter, ADPC), archive funds T (Sports and Education) and M (General Administration): T.supp I45 (Information packs of the sports societies, I920s-1930s); T.supp 272 (Information about sports societies, I923-1924); M 2223 (List of sports societies, I924).

I6. About this process, see Julien Sorez, Le football dans Paris et ses banlienes (Rennes, 2013), pp. 7I-II 8. 


\section{POLISH MIGRATION AFTER WORLD WAR I}

Polish migrants started to arrive in the coalfield in the I920s. They were not the first: the mining industry had attracted foreign workers, most of them from Belgium, since the nineteenth century. ${ }^{17}$ Nevertheless, a real change could be observed in the I920s. After World War I, the mining employers were in need of additional manpower and sought to recruit labour from abroad, first to rebuild the mining installations and related production facilities, and later to enable the growth of coal production. A minority of these immigrants came from the Rhineland-Westphalia industrial region in Germany, but most of them were Polish peasants arriving directly from Poland. Polish emigration was based on an intergovernmental agreement between France and the new state of Poland, with the support of the largest employers' union in the coalmining industry, the Comite Central des Houillères de France. ${ }^{8}$ Women and children followed the men, and migration became massive: Polish workers had numbered only I 3,000 in the north in I92I, yet reached 90,000 in I926. They were concentrated in the coalmining area and made up a large proportion of the mining workforce. In the small town of Ostricourt, for example, the proportion of foreigners reached 70 per cent, almost all Poles.

Nearly all the immigrants were employed in the coalmining industry. Many companies employing the new miners tried to preserve them from "contamination" by trade unions or left-wing political parties. For their part, the Polish miners saw migration as a temporary affair and thought they would return to their home country after some years. Integration into French society was not their aim at that point. As a result, Polish migration at first led to the construction of segregated Polish communities within the French mining district, emerging as true Petites Polognes, that is to say, highly organized communities with their own shops, churches, and associations. In many villages, there were quarters or streets where everyone was Polish. These communities were rooted in national and religious values, and "identified" with Catholic Poland ${ }^{19}$ - a phenomenon that arose with the active support of the mining companies, which contributed to the payments made to the Polish priests appointed by the Mission catholique polonaise and supported schools with Polish-language classes. A similar phenomenon could be seen in the Ruhr before I9I $4 .{ }^{20}$

17. Judith Rainhorn, "Le Nord-Pas-de-Calais, une région frontalière au cœur de l'Europe", Hommes et migrations, I 273 (May-June 2008), pp. I 8-34, 2 I-25.

I8. Janine Ponty, Polonais méconnus. Histoire des travailleurs immigrés en France dans l'entredeux-guerres (Paris, 1988), pp. 35-8I.

19. See also the article by Philip Slaby in this Special Issue.

20. Diethelm Blecking, "Sport and Immigration in Germany", The International Journal of the History of Sport, 25 (2008), pp. 955-973, 957-960. See, too, Diethelm Blecking's contribution to this Special Issue. 
The policies of the companies and the strong national and cultural consciousness in these Polish communities engendered, at first, mutual segregation. Until the I940s, Polish migrants were excluded from local society. Poles were seen as foreigners because of their language, their customs, and their demonstrative expression of Catholic piety (whereas French miners often kept a distance from the Catholic Church). They were disparagingly dubbed Polaks and often had to endure racist insults from other miners. ${ }^{21}$ French workers, along with engineers and foremen, also called them Boches (a racist insult referring to the Germans in World War I), cul-bénits, or curetons ("prayboys"). In the opposition between "us" (the members of the local working class) and "them" (the others), Poles were firmly placed on the side of "them"; they were regarded as being outside the community and were seen as a threat and a source of division.

\section{POLES AND FOOTB ALL BEFORE AND AFTER WORLD WAR II}

The segregation and exclusion of immigrants also held true in the arena of sports and leisure. This exclusion explains why Polish migrants created a peculiar and closed associative framework - in sports, music, and elsewhere to assert their cultural and national identity, similar to the framework they had constructed in Germany before World War I. ${ }^{22}$ Gymnastic events at the Sokol clubs, ${ }^{23}$ cycling races, and football matches allowed migrants to get together; they could speak their own language and the sports festivities fostered a sense of community. For instance, in the mining district of Lens two Sokol associations were founded in the mid-r920s. After some years, in the same place, three Polish football clubs were established. The three teams were based on neighbourly relations: all team members lived in the same neighbourhood. Their establishment reflected the fact that Polish miners wanted to act on their own initiative and to play together within structures of their own creation. ${ }^{24}$ With the same goal, they created autonomous federations such as the Fédération Polonaise de football en France, founded in 1924 (also known as the Polski Zwiarek Pitki Noznej [we Francji] - PZPN).

In addition to the individual clubs, these kinds of large social and sporting organizations offered opportunities for meetings and competitions to their members, allowing them to play without having to connect with the French sporting associations. This type of federation embodied the Polish

2 I. Janine Ponty, Les Polonais du Nord ou la mémoire des corons (Paris, 2008), p. 42.

22. Blecking, "Sport and Immigration in Germany".

23. These were specific gymnastic clubs that played a major role in the building of Polish/Slavic cultural and national identity: Diethelm Blecking (ed.), Die slawische Sokolbewegung. Beiträge zur Geschichte von Sport und Nationalismus in Osteuropa (Dortmund, 1991).

24. See ADPC, archives of the "Sous-préfecture de Béthune", IZ IOI 7, report of the "sous-préfet de Béthune" to the "préfet du Pas-de-Calais" about the PZPN, autumn I939. 
community and contributed to the poor integration of these migrants into French society. These organizations were substantial in number and size: in I 937 there were I I 2 Sokols, I 33 shooting clubs, and 27 football clubs in the northern coalmining region; the latter were affiliated to the PZPN. ${ }^{25}$ As with the dynamics in the German Ruhr, the sporting networks sustained a sense of Polish identity in a foreign country. The sports associations thus strengthened the ethnic borders that divided the mining community.

But this situation did not last. In the I930s and I940s there was a change, initially for sport-related reasons: starting in the 1930s, football spread among miners and among the French working class in general. This new preference changed the situation for sport activities, as football and gymnastics did not play precisely the same role within the community.

Gymnastic activities were almost always organized within the framework of formalized associations, as was the case with the Sokols. This framework helped the Sokols to become an excellent medium for the promotion of Polish national identity, by means of special open-air exercises, with flags, banners, and uniforms worn by the gymnasts during the great mass festivities. In such events, Polish identity was very visible. But football had a more ambiguous side. The rules of the game were the same in the clubs in the PZPN and in the Fédération Française de Football (FFF). At the same time, the clubs in the Polish federation were often smaller and had fewer opportunities for prestigious matches. Additionally, in contrast to the Sokols, the PZPN clubs were less particular to the Polish community and less capable of embodying the Polish national identity. In other words, their function and their utility were less obvious. Under these circumstances, it was no wonder that many Polish children or teenagers soon preferred to play in French clubs, which had more resources and better competitive opportunities. By the 1930s, for example, children of Polish migrants comprised 30 per cent of the team of the Association Sainte-Barbe d'Oignies, an important non-professional mining club. ${ }^{26}$

There was another difference between gymnastics and football. Unlike gymnastics, football could be played informally, frequently in the form of street football, which was of great importance in the mining quarters, which functioned like urban villages. ${ }^{27}$ As the British historian Richard Holt wrote:

What seems to be clear is that such teams often sprang from a formalizing of casual street relationships, bringing a shape and a continuity to that most basic of feelings - the sense of place. [...] Organized teams provided a bridge between the childish and the adult male world, a means by which the playful enthusiasm of

25. Olivier Chovaux, "Le football, un exemple 'd'intégration de surface' dans l'entre-deuxguerres”, in Marie Cegarra (ed.), Tous gueules noires (Lewarde, 2006), pp. I38-1 5 I, I 45.

26. Archives Nationales du Monde du Travail, Roubaix, France, 19940570015 , Players' list of the “Association Sainte-Barbe d'Oignies" (1941-1942).

27. Grégory Frackowiak, "Théodore Szkudlapski dit Théo. Essai de biographie d'un 'galibot footballeur'”, Revue du Nord, 355 (2004), pp. 367-389, 369. 
boys was turned into the tougher style of men. Here boys learned how to drink and tell jokes as well as the language of physical aggression. ${ }^{28}$

This kind of learning was common for children of both French and Polish miners. They discovered football at the same time and they played together in the streets of the mining districts. This shared learning experience was undoubtedly an early way to bring young French natives and migrants' children together. The team's identity was no longer based on nationality or ethnicity, but on the neighbourhood and the local community. Football, especially, allowed the young Poles to erase the stigma of their origins: they were no longer seen as foreigners with "strange" names, language, and customs; they were now recognized as good players and sometimes as local sports heroes. ${ }^{29}$

This evolution became more and more pronounced after World War II, a very turbulent period for the northern coalmining region. Shortly after France had been liberated from German occupation, the mining companies were nationalized and those in the north were grouped into a new organization, the Houillères nationales du Bassin Nord-Pas-de-Calais [National Collieries of Nord-Pas-de-Calais Basin]. Nevertheless, frustration and anger among mineworkers lingered on, and the situation remained very tense until the end of the I940s, especially during the massive wave of strikes in 1947-1948, which saw violent conflicts between strikers and non-strikers, and eventually led to harsh repression. ${ }^{30}$ The unrest also affected the sports organizations in the mining district. On the one hand, there was much enthusiasm, thanks both to the end of the war and to nationalization, which sparked the dream of a profound, revolutionary change in society. This enthusiasm encouraged French and Polish miners to become closer. On the other hand, mining communities were now divided more than ever before. The French Communist Party continued to grow in number and influence among the miners, and denounced all representatives of the social and symbolic power of the company, including engineers, foremen, teachers, and priests. ${ }^{3 \mathrm{I}}$ The Polish migrants were divided into supporters of the new communist government of Poland and supporters of traditional, Catholic Poland. ${ }^{32}$

However, football grew in significance in the mining communities, and this growth became even more rapid following the disappearance of many

28. Richard Holt, "Working Class Football and the City: The Problem of Continuity", The British Journal of Sports History, 3 (1986), pp. 5-17, 7.

29. Beaud and Noiriel, "L'immigration dans le football", p. 92.

30. Marion Fontaine and Xavier Vigna, "La grève des mineurs de l'automne 1948 en France", Vingtième Siècle: Revue d'bistoire, I 2 I (20I4), pp. 2 I-34.

31. Dubar et al., "Sociabilités minière et changement social", pp. 379-400; Augustin Viseux, Mineur de fond: fosses de Lens, soixante ans de combat et de solidarité (Paris, 1994), pp. 382-400. 32. Joël Michel, "La seconde guerre mondiale et l'évolution de la communauté polonaise du Nord de la France", Revue du Nord, 226 (1975), pp. 403-420, 410-4I 2. 
of the old gymnastics associations that had been previously controlled by the companies. In the small mining village of Wingles, for example, there was no longer just one team but four, which reflected old and new rivalries within the community: skilled versus unskilled miners, or gymnasts from the old mining association versus young and committed members of the new football clubs (which were supported by the communists). On the other hand, clubs in other small communities became more unified. Thus in the mining quarter of Saint-Pierre in Lens, a Serbian migrant, Jean Kravanja, created a new football club. His club was rooted in community life: its headquarters were located in a café, the team played on a playground in the neighbourhood, and it aimed to bring together all local residents. ${ }^{33}$ This type of sports community was supported by a new sense of local identity: all the players and all the fans lived in the same place, often worked in the same pit, and were often affiliated with the Communist Party, the miners' union, or both. This shared identity became more important, while the difference between old inhabitants and new migrants (or their children) became increasingly weaker. Gradually, the small PZPN clubs became a thing of the past.

POLISH PLAYERS AND THEIR FANS: RACING CLUB DE LENS

This kind of development - consolidation and increasing identification by the whole local community - can also be observed in professional football, as becomes clear in the case of Racing Club de Lens ("Racing"). ${ }^{34}$ In the I930s, this team was transformed into a professional club, controlled by the mining company in Lens. Racing's rise to prominence was part of a marketing strategy. The company directors wanted to build a successful, prestigious team to attract spectators and foster the reputation of the company. In this context, the club also attracted migrant players, but these were Hungarian or Austrian professionals who had been integrated into the international sports labour market and not Polish miners living in the neighbourhood. ${ }^{35}$

After World War II, the situation changed profoundly. In 1958, for instance, most of Racing's players came from Polish mining families and they had spent their childhood in the coalfield of the north.

33. ADPC, archive fund M (General Administration), M 69 is (List of new sports societies, 19391947). For references to this new club, see also the following local newspaper reports: Artois-Sports, I I March 1947; La Tribune des Mineurs, I6 August 1947, I3 September 1947. 34. For a similar case, see Siegfried Gehrmann, "Football in an Industrial Region: The Example of Schalke ${ }_{4}$ Football Club", The International Journal of the History of Sport, 6 (I989), pp. $335-355$.

35. Olivier Chovaux, "Football minier et immigration. Les limites de l'intégration sportive dans les années trente", STAPS, 56 (200I), pp. 9-I8, I I-I 4. 


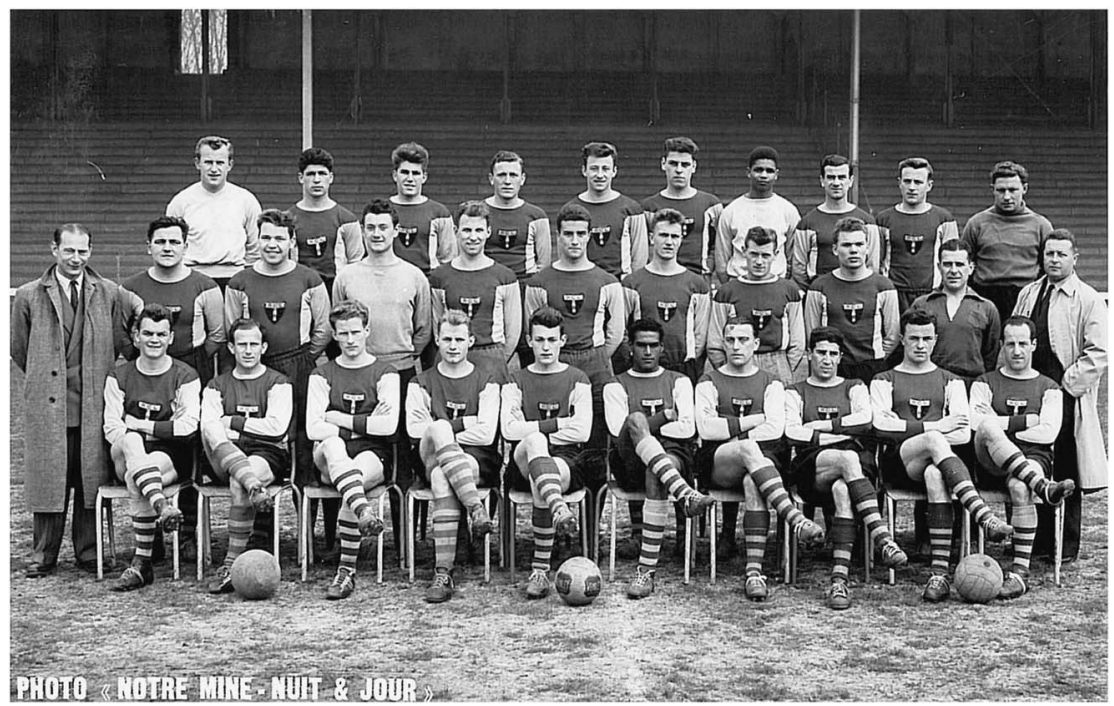

Figure 3. The RCL's team for the 1955-1956 season. Back row (left to right): Sowinski, Sarrazin, Carlier, Wattecamps, Wisniewski, Stiévenard, Dobat, Aurednik, Dumoulin, Duffuler. Middle row (left to right): Marek (coach), Klaus, Jonsson, Clément, Oswarzak, Courtin, Théo, Ziemczak, Ganczarzik, Battut, Trannin (manager). Front row (left to right): Trela, Habitzl, Kowalkowski, Polak, Demay, Louis, Marresch, Hassouna, Raspotnik, Boury.

Archives Municipales de Lens [4Figi4]. Used with permission.

They included Kowalkowski, Ziemczak, Sowinski, Wisniewski, Placzek, and Szkudlapski. ${ }^{36}$ A new generation of migrants was now able to penetrate professional football. This evolution can be explained by many factors, including the impact of nationalization. While the Houillères nationales continued to support local amateur sporting clubs - paternalism was not abolished by nationalization - they wanted the management of Racing to be more rational and less costly. As a consequence, Racing's leading representatives could no longer recruit players on the international market in the way they had before, and they had to turn to the human resources of the local coalfield. Moreover, following the tensions that marked the late I940s, the managers of the Houillères nationales wanted to consolidate the unity of the mining community. They became increasingly interested in the potential role of the Racing football club, not only for marketing purposes but also as a source of social appeasement and cohesion.

These economic and social considerations led Racing's managers to change their approach to recruitment. Now they openly addressed the 
miners' children, playing in non-professional mining clubs. The directors of these clubs (often mining engineers) sent the best young players to Racing's managers. Through this deep-rooted network new promising players could be identified, such as Maryan Wisniewski (from Auchel) or the Lech brothers (Georges and Bernard Lech from Montigny-en-Gohelle). With this decidedly local model of recruitment, Racing's team became a reflection of the coalfield's population, including the Polish migrants among them. Conversely, the migrants became more conscious of the advantages of professional sports within the context of mining.

After World War II, Polish nationalism became a thing of the past and "assimilation" was the new watchword for migrants and their children. While, at that time, a career in professional football did not lead to "great" stardom, a young man who was a good player could gain better opportunities within the mining world. Racing's recruiters promised young players and their families jobs in offices or in technical services (rather than in the pits). They could earn a wage both as a player and as an employee of the Houillères nationales, and thereby hope for a better social position. As a non-professional player in Noeux-les-Mines, before he became famous, Raymond Kopa's long-cherished dream was not to become a professional footballer; rather, he saw the job of footballer as a stepping stone to a position as an electrician within the mining company. ${ }^{37}$

I will not dwell too much on Raymond Kopa, as his national and international career makes his case rather exceptional; the same goes for Maryan Wisniewski. For younger, less prestigious players, such as Theodore Szkudlapski, playing for Racing from I 953 to $1958,{ }^{38}$ or Arnold Sowinski, who played for Racing during his entire career, ${ }^{39}$ integration into the local team provided material benefits, while allowing them to take advantage of the social rights associated with the mining profession. Those privileges came at a price, however. The mining context always prevailed, and young footballers had to be serious, modest, and respectful workers. ${ }^{4}{ }^{\circ}$ Most young Polish players thus had only a local career. They remained under the control of the Houillères nationales and were dominated by the mining managers of the club.

The relationships between these young Polish players and their fans was even more complicated. In the I950s and I960s, supporters became increasingly organized and came out in greater and greater numbers to support "their" team, which was considered the symbol of the local

37. Beaud and Noiriel, "L'immigration dans le football", p. 89.

38. Frackowiak, "Théodore Szkudlapski dit Théo".

39. The information about Sowinski's career is based on an interview with Arnold Sowinski, 23 January 1999.

40. For typical statements of this sort see, for instance, the interview with Eugène Hanquez (HBNPC engineer in Lens), 9 November 1998. 
mining community. ${ }^{4 \mathrm{I}}$ For the fans, Racing's players had to embody the values of the ideal miner, like hard work, indomitable courage, and solidarity, and the team's offensive style of play was expected to reflect these values by privileging teamwork over the showing off of individual stars. ${ }^{42}$ If the players succeeded, spectators would speak of them as "our boys". They were no longer seen as foreigners or as Polaks, but as representatives par excellence of the local community.

Yet even in this case there was a proverbial fly in the ointment. The players were admired, but also envied by their supporters, due to the special privileges they were granted by the companies: their work in the mines was a well-known fiction, yet they received higher pay than the others. In addition, the pressure from neighbours and from the local community in general could be very strong. As the footballer Stephan Ziemczak remembered:

In Lens, we had the good and the bad fortune of being from the area. At the stadium or at home, you always saw the same thing. Your neighbour, he went to the match; the guy across the street, he went to the match; the guy who worked in the mine with my father, he went to the match. You would never leave that environment: I was my father's son, but also my neighbour's. You always had the feeling that you owed them something. ${ }^{43}$

If the spectacle of football thus helped to erase some of the old frontiers between native inhabitants and the children of Polish migrants - achieved in large part by turning the latter into standard-bearers of the mining community's values - it nevertheless continued to nurture all other distinctions and divisions that characterized this community.

\section{FOOTBALL, NORTH AFRICAN MIGRANTS, AND THE CRISIS OF THE MINING MODEL}

As described above, between the I940s and the r960s a social and sporting model rooted in the framework of mining became apparent. However, the relationship between sports, immigration, and integration cannot be told by referring to Polish immigrants alone. Indeed, the mining industry did not stop attracting migrants after $1945 .{ }^{44}$ However, the new waves of migrants arriving in the northern coalmining area after World War II did so in a

4I. The fans were organized in the Supporters Club Lensois (SCL), which was also supported by the HBNPC. Since the end of the I940s SCL has published a newspaper, Sang et Or, journal du RCL et du Supporteurs Club Lensois.

42. There was a similar phenomenon in English working-class football; see Richard Holt, "La tradition ouvriériste du football anglais", Actes de la Recherche en Sciences Sociales, I03 (1994), pp. $3^{6-40 .}$

43. Quoted by Frackowiak, "Théodore Szkudlapski dit Théo", p. 373.

44. For an overview of post-1945 waves of immigration see Rainhorn, "Le Nord-Pas-de-Calais", pp. 27-3I. 
different situation, one less clearly marked by expansion. Just after the war, the mining industry needed a foreign workforce for the reconstruction of the mines and to meet growing energy needs. The Houillères nationales started to recruit new workers from Algeria. Employing this group of migrants had many advantages for the employers: the immigrant workforce was young, available, and relatively inexpensive, as Algerian migrants had fewer rights compared with other miners with respect to wages and labour conditions. Moreover, recruitment was easy because of the colonial system: until I962, Algerian indigènes were theoretically considered to be French, and there were no restrictions on their mobility in metropolitan France. Under these conditions, more than 20,000 Algerians came to work in the northern pits.

From the I960s, however, the mining industry was hit by an economic crisis that would, in the decades to come, never really abate. ${ }^{45}$ Coal had to compete with oil, and the French coalmining industry was increasingly considered unprofitable. In 1959, the French government began to organize the closure of the pits with the Plan Jeanneney, followed by the Plan Bettencourt in 1968. The crisis successively diminished the economic and political weight of the Houillères nationales. But this process was very slow, spanning more than three decades, and it was not linear. Coal production became less and less important overall, but under certain circumstances (for instance, after the I 973 oil crisis) production did increase again slightly for a few years. In this context, the Houillères nationales still recruited migrant workers, not to enable production to grow, but to control the process of downsizing.

In the I960s the mining company could still bring in migrant workers. During this period around 70,000 Moroccan migrants from rural areas were recruited on temporary, I 8 -month contracts to work in the pits in the north. ${ }^{46}$ This arrangement provided the employers with a precarious workforce to satisfy the needs of a volatile coal production, with considerable ups and downs, while the closure of the pits was pending. Hiring Moroccan migrants was a way to maintain social peace and to close the pits without damage to the "established" miners. Generally speaking, these two generations of North African workers - arriving after the war and in the I960s - were largely excluded from the mining community. They were often single and lived in barracks, remote from the inhabitants of the mining quarters. Their wages were low and they were considered secondary workers. They were not incorporated into existing regulations concerning mining labour or social insurance. Moroccans had to organize two major

45. Marion Fontaine, Fin d'un monde ouvrier. Liévin, 1974 (Paris, 2014), ch. I.

46. On the experience of Moroccan miners in the Nord-Pas-de-Calais, see Marie Cegarra, La mémoire confisquée. Les mineurs marocains dans le Nord de la France (Lille, I999). It is noteworthy that whereas Polish migration to the Nord-Pas-de-Calais has produced a stream of academic studies, so far relatively little has been published on North African immigration to the region. 
strikes, in 1980 and 1987 , to obtain the rights and benefits of the Statut $d u$ mineur in the realms of housing, social insurance, health care, and holidays which had been acquired by the established miners after nationalization.

Polish and North African migrants shared some of the same features. In both cases, they were rural migrants who had experienced the uprooting of migration and a rupture in their traditional identities. Both migrant communities also fell victim, at least initially, to the exclusionary reactions of native inhabitants, who denounced the foreignness of their respective languages, culinary customs, and religious practices. But there were also important differences: before the 1960s, Moroccans and Algerians were not citizens but "Muslim subjects" (or indigènes) in the French colonial empire, and with that designation came a type of subordination and racism that the Poles had not experienced. The context of their arrival differed considerably as well. Polish workers lived through a very agitated social and political history (the crises of the I930s, the war, nationalization, and the major strikes of I947-I948), but in this period paternalist social policies were strongly developed and the mining communities were very much alive. The North African miners, by contrast, worked in a seemingly calm period, though in reality it saw a successive breakdown of the mining sector and of the mining communities.

These differences - both relating to the origins of the migrants and to the social dynamics of the mining community - help explain the differences between the two migrant groups. The Poles had emigrated as families, and had been able to maintain and organize their own social networks (both within and outside the world of sports) with the support of the mining companies. These social networks allowed Polish migrants to reconstitute community life, and their children eventually to integrate into the political, social, trade-union, and sporting life of the local community. In contrast, the Algerians - and even more so, the Moroccans - remained very isolated (the men were reunited very slowly with their families), with little sense of community and without the support of the Houillères nationales, which, after the mines had closed, lost interest in their fate. In this context, the older Moroccan miners lost the possibility of integrating into local workers' groups: such groups were already falling apart and losing their unionizing and political power. They did not survive much longer, except as a sense of nostalgia for an idealized mining past.

THE NEW RACING CLUB DE LENS, ITS PLAYERS, AND THE COMMUNITY

The crisis in the mining model also had an impact on local sports, as can once more be demonstrated by the case of Racing Club de Lens. ${ }^{47}$ As the 
Houillères nationales stopped supporting the club, it felt the full thrust of the crisis in the mining industry, to the point of near-extinction towards the end of the ig6os. However, the club managed to revive in the early i 970 s thanks to support from a few local companies and also from the municipality of Lens. The city did not want to see Racing disappear, as it had become one of the rare elements of unity in a city disrupted by de-industrialization and the closure of the mines. In the I970s, the club again enjoyed a measure of success in the national championships, and also in the new European competitions. Such success enabled Racing to develop a proper brand image, based upon its former mining background. Racing was thus described and represented as a "popular" and "modest" club, composed of local players who retained the old miners' playing style: a desire to win based on guts, courage, and solidarity, rather than on technical finesse..$^{4}$ This was the discourse not only of the media and the new club directors. The supporters, who reorganized themselves during the I970s, adhered to it and identified with this image of the club. Although this was a destructive period for the identity of working-class communities, Racing appeared as a source of stability around which the local community could rally.

Yet, by the I970s the Racing team had experienced a profound transformation, due in part to the changes that affected its surroundings, but also to the changing landscape of professional football. ${ }^{49}$ Football clubs were increasingly becoming veritable entertainment companies, which recruited players through an increasingly powerful and internationalized sports market. Even if its financial means were modest, the new Racing did not escape this trend. The recruitment of players could no longer rely upon the network of mining clubs, which were disappearing along with the mines themselves. The club started to recruit footballers increasingly from the sports market, much as it had done during the I930s. One might object that the lensoise team of the I 970 s nevertheless still included a certain number of Polish players among its ranks: Richard Gregorczyk, Joachim Marx, and Eugenius Faber. But these "new Poles" had nothing in common with the preceding generation, nor with the immigration of the Polish workers who had established roots in the northern basin. Instead, they were purely professional athletes, who had come of age in a European sports market. The "new Poles" reinforced the image of Racing being a "mining" and "working-class club", but such designations had become no more than a convenient illusion.

Moreover, this illusion could operate as a factor of exclusion as well. With a few exceptions, such as Farès Bousdira (though he did not come from a

48. See, for instance, Private Archives of the Racing Club de Lens, Lens, Pas-de-Calais (France), Association des relations publiques du RCL, Plaquette du joe anniversaire $d u$ RCL, 1976.

49. Anthony King, The European Ritual: Football in the New Europe (Aldershot, 2003), pp. 37-66. 
mining background), the club of the I970s did not tap the well of maghrébin immigrants who had come to the region to "close the mines". The cutting off of Racing from the last local migratory wave was primarily due to the weakening of the mining companies and the end of their informal recruitment channels, which had given the Lens-based club its local (Polish) colour. In this respect, the recruitment of players like Faber and Gregorczyk, which in theory could have served to reinforce this image, was more an indication of a loss: it signalled the irreversible rupture with the selection mechanisms belonging to the age of the Houillères, and the need to turn towards the domestic and European markets for players. Thus, the processes that had worked for the sons of Polish migrants would no longer work for the children of the Moroccans and Algerians.

This absence brought trouble. The "Polish-ization" of Racing's team had been less a cause than a result of the increasing integration of Polish-born children into the mining world and the local community. But football had also played an active role in this integration by mitigating social stigma and discrimination. Through sports (as a game and a show), those formerly known as Polaks had become "our boys", representing the dignity and values of courage and solidarity of the mining community. In this way, they had become symbols of the "good" migrants in local collective memory, both in terms of mining work and sports. The Moroccan and Algerian migrants, however, were excluded from this positive memory. More dangerously, even, this exclusion could contribute to a racist attitude: to some, North African migrants could not become "good" miners or "good" players, and were blamed for being "bad" migrants, in contrast with the Poles. In 1998 the mayor of Lens, André Delelis, said:

What people like here is that footballers play like miners: effort is a quality that comes before playing technique. Poles were exceptional players in this respect, because the Pole is a hard worker, a tenacious man, who never gives up, disciplined, a little like a German. One can always count on him. That is why the Polish footballers have been more successful than the North African players. There were Algerian and Moroccan migrants here, but on the sports field they have never given the same things as the Polish migrants. ${ }^{50}$

As becomes clear in this statement, a situation brought about by social factors (the crisis of the mining model and the reorganization of the way footballers were recruited) could, at a certain point, perpetuate racist stereotypes.

\section{THE PARADOX OF AHMED OUDJANI}

The mayor's declaration evoked Racing's past at the time of the coal industry's golden age in the r950s and I960s. But he seemed to have

50. Interview with Andre Delelis, 9 January 1999. 
forgotten that in that period the team's greatest heroes were not exclusively of Polish descent either. Indeed, from the end of the r950s until the I970s one of the most famous players in the team was an Algerian, Ahmed Oudjani. ${ }^{5 \mathrm{I}} \mathrm{He}$ was recruited by the club in 1957 and played there until the beginning of the I 970 , before finding a job as football coach. To this day, he remains the best scorer in the club's history.

Yet Oudjani was the result of sports immigration and he had no connection with the Algerian miners who came to the coalfield. He began his sports career in the district of Oran (Algeria) and was recruited by the French club Vendôme (in the département Loire-et-Cher). He was then selected by Racing's coaches, who contracted him for their professional team. As shown above, in theory the leading representatives of the club (all of them related to mining) had to favour local players rooted in the mining community. But there were limits to this principle, and the club needed some experienced players to step up its game and to continue to attract spectators. Thus even in the post-nationalization period Racing's managers tried to recruit smaller "stars", such as the Antillean player Xercès Louis and the Algerian Ahmed Oudjani. The situation of this type of player was actually very similar to Racing's foreign players in the I930s and, not surprisingly, it differed considerably from that of the young "Polish" players recruited by the club on the basis of the mining model. Like the other foreigners or "stars" of Racing - that is to say, the players selected within the framework of the sports labour market - Ahmed Oudjani could enjoy some specific privileges and advantages. Unlike the younger Polish-born players, he was considered a professional footballer, who had been recruited and was paid to play football only. He lived with his family in downtown Lens and not on one of the mining streets. The young Polish players were "miner-footballers" and had to follow the binding rules of the mining company and to respect the customs of the mining community, whereas Ahmed Oudjani enjoyed considerably more freedom.

Nevertheless, Ahmed Oudjani - called "Médo" by the supporters - was quickly adopted by the community and became a popular figure in the life of the mining neighbourhoods. He was a tough player and a great scorer, and he won a big audience among the miners, who made up a large part of Racing's fans. They identified with the courage of "Médo" and with his physical style of play. Ahmed Oudjani accepted the domain and customs of the neighbourhood and he was said to take part in conversations at the pub or in the street without difficulty. In short, he succeeded in embodying the rules and values of the mining community even better than many

51. Information about Ahmed Oudjani is based partly on an interview conducted with his widow and sons (Yacine and Chérif Oudjani), 5 and 7 November 2007. See also Marion Fontaine, "Les Oudjani et le 'club des Gueules Noires'. Parcours et représentations (années i960-années i980)”, Migrance, 29 (2008), pp. 89-95. 
young, Polish-born migrants or players. Over the years players such as Theodore Szkudlapski or Stephan Ziemczak, though born in the mining community and well-acquainted with its codes, often found themselves criticized by fans reproaching them for lack of discipline or for a desire to shine individually, and thus for deviating from the mining values that the team was supposed to represent. ${ }^{52}$ In contrast, Ahmed Oudjani, who initially had no ties to the mining community, was well liked among Racing's supporters. To borrow from the racial stereotypes evoked earlier by the mayor of Lens, it might be said that Oudjani had a style that was more "Polish" than some of the Poles on the team themselves. This paradox shows the fragility of the supposed relationship between players' ethnic origins and their playing style and, more broadly, demonstrates the complexity of the relationship between sports and migration. ${ }^{53}$

However, Ahmed Oudjani remained an isolated symbol. In the case of the Polish migrants, the practice of playing football gained significance for the migrants' children, who from a certain moment on were likely to play in French football clubs rather than in clubs that represented a national and cultural Polish identity. Their insertion into the local sports culture was an important way for the Poles to establish roots in the local mining community, to the extent that some of them became community sports symbols in local collective memory. Ahmed Oudjani's success, however, did not testify to such a process and remained an exception. The children of Algerian or Moroccan migrants never became typical recruitees in the eyes of Racing Club de Lens. Though these children might be present today in the non-professional football clubs of the old northern coalfield, ${ }^{54}$ they were absent from the roster of the local professional team. Currently, Racing's team no longer reflects the social composition of the local community and serves instead to reinforce, at least at a symbolic level, the exclusion of the most recent migrants. Ahmed Oudjani may have succeeded in establishing roots within the mining community, but the stigma has not changed for other North African migrants.

\section{CONCLUSION}

Several conclusions can be drawn from an analysis of the influence of sports, particularly football, on the relationship between natives and migrants in the northern mining community. For one, it should be noted that sport was not an isolated affair, but part of both the management of the mining industry and of the lives of the local community of workers.

52. For a typical example from the late i950s of such a reproach, see Liberté, 5 June 1956.

53. Beaud and Noiriel, "L'immigration dans le football", pp. 94-96.

54. As Yacine Oudjani pointed out in the interview conducted on 7 November 2007. 
As such, sport reflected the evolution of that industry and that community. One of the consequences of this was that mining paternalism continued to carry weight until the late twentieth century, and that the nationalization of mining companies did not alter this phenomenon. This close entanglement of the worlds of mining proper and its surrounding communities, in turn, allows one to better understand the crisis of the mining model and its consequences, which extended far beyond the closing of the mines.

The second major observation concerns the difference between the treatment of "old immigration" (that of the Poles) and "new immigration" (that of the North Africans): while the former succeeded, slowly and with some difficulty, in establishing new roots in the local community, the latter remains largely excluded from that community even today. This difference can be attributed less to ethnic and cultural causes (for example, the difference between European and postcolonial immigration) than to a difference in context. The Poles' success in taking root can be explained in large part by the social and political strength of the mining model at the moment of their arrival. In contrast, the North Africans can be seen as having "paid" the cost of the mining crisis, suffering especially from the disappearance of the social politics of the Houillères nationales and from the fragmentation of the local mining community.

All this seems to suggest that sport is not an automatic mechanism of integration nor of exclusion; instead it has ambivalent effects that can vary according to the cultural moment and the community's specific situation. The exploration of the phenomenon of sport thus invites approaches that are at once nuanced and sensitive to the particularities of mining cultures. These cultures should be observed closely - small worlds in themselves - at different levels (local, national, and international) in order to analyse the simultaneous operations of mining companies and the lives of communities that both arose and died in the vicinity of the mines. 